\title{
The Effect of Using Cell Phone Dictionary on Improving Male and Female Iranian EFL Learners' Spelling
}

\author{
Amir Reza Nemat Tabrizi ${ }^{1} \&$ Mohammad Bagheri Fard ${ }^{1}$ \\ ${ }^{1}$ Department of English Language, Payame Nour University, Iran \\ Correspondence: Amir Reza Nemat Tabrizi, Department of English Language, Payame Nour University, Iran. \\ E-mail: arnemati@pnu.ac.ir
}

Received: July 3, 2016 Accepted: October 30, 2016 Online Published: November 23, 2016

doi:10.5539/ijel.v6n6p175 URL: http://dx.doi.org/10.5539/ijel.v6n6p175

\begin{abstract}
This paper attempts to investigate the effect of using cell phone dictionaries on improving male and female Iranian high school EFL learners' spelling. To this end, ninety participants were randomly selected from Dinodanesh and Etrat high schools in Lordegan city, and they were given a spelling pretest based on their course book. Then sixty subjects whose scores were within the range of one standard deviation above and below the mean were selected as homogeneous and divided into experimental and control groups. Using cell phone dictionaries was conducted in eight class session, during which experimental group received training with cell phone dictionaries while the control group only received training without any cell phone dictionaries. The data were collected via a pretest and a posttest. The analysis of the test scores using t-test revealed that the experimental group did statistically better in the test. The results revealed that using cell phone dictionary had positive effect on improving EFL learners' spelling. At the end, a two-way ANOVA was run to compare the two groups plus the effect of gender on such performance. The results indicated that treatment have an effect on the improving of both male and female EFL learners' spelling.
\end{abstract}

\section{Introduction}

\subsection{Introducing the Problem}

In recent years, researchers have witnessed the concomitant rise of cell phone assisted language learning in educational and academic settings. Nowadays education is more and more taking advantage of Information Technology. One of the most attractive technological devices is the mobile phone which represents a revolution in education. The traditional classroom, blackboard, and textbooks can no longer satisfy the needs of generations of students used to handle technological tools since their childhood. Today almost everybody uses mobile phones.

In the world that emerging technology-supported devices are rapidly growing, wireless communication technology is not an exception in this respect. As cell phones with high capabilities extend into all areas of human life, it is expected that this wireless computing device soon becomes accessible for all urban and rural areas of each country. So, widespread access to such an inexpensive and sophisticated device has rather changed the landscape of e-learning in many ways. In fact, cell phone learning can be considered as the next generation of e-learning.

Cell phone devices are not substitute for existing learning devices, but they serve as extension for learning in new environment having new capabilities, though, not all learning content and activities are appropriate for cell phone devices.

\subsection{Importance of the Problem}

According to Canny (Miangah \& Nezarat, 2012), cell phones offer an ideal platform for learning since they are ubiquitous, affordable, compact and wireless. Cell phone applications which have been mainly used in language learning include short message service (SMS), recording voice services and email services. However, some applications and their role in language learning have been neglected. One such type of applications is dictionary. The usage of dictionary in cell phones and its probable impact on student spelling has been overlooked in the literature.

Ubiquity of cell phone dictionaries as well as the importance of spelling learning as a fundamental part of any language learning program was the main impetus for this study exploring whether or not the use of cell phone dictionaries have any effect on improving Iranian high school EFL learners' spelling. Moreover, the learners' 
attitude toward the use of these applications was sought.

\subsection{Relevant Scholarship}

One of the technologies that can be used to help learners in learning a foreign language is cellphones which are dominant in most students. They are useful computers that fit into students, pockets, are always with them and nearly always on, and can be used in any kind of learning (Prensky, 2005). This technology has brought about a new type of language learning called Mobile Assisted Language Learning. As a form of technology, mobile assisted language learning (MALL) is a branch of technology enhanced learning which can be implemented in numerous forms including face to face, distant or online modes. However, different scholars in the field have underscored that MALL should be implemented in the classroom, taking the presence of learners as a paramount factor into consideration. As Colpaert (2004) has rightly argued, before using mobile technologies a learning environment should be fostered. Likewise, Salaberry (2001) has argued against "technology driven pedagogy" emphasizing the fact that despite their considerable benefits nothing to date has proved that any type of technology can necessarily act better than traditional forms of teaching. Finally, as Beatty (2003) has asserted, "Teachers need to be concerned about investigating time and money in unproven technology" (p. 72). All in all, using any kind of technological device should be accompanied by developing an efficacious type of methodology because these devices are not instructors but rather instructional tools.

In a study in Japan Thornton \& Houser (2005) examined the use of cell phones in education. In this study students were surveyed regarding their use of mobile phones. English vocabulary lessons were sent to the learners' mobile phones using short text messages and a website was developed to explain the English idioms which students surfed using the $3 \mathrm{G}$ phones. The findings revealed that mobile phones are ubiquitous among students and learners were ready to read small texts on mobile screens. It was noted that mobile phones can effectively serve to educate a foreign language learner and short text messages is very useful in teaching vocabulary.

\subsection{Research Hypotheses}

In this study, the subjects were selected randomly, and there was a treatment for the experimental groups, the true experimental design is considered the most appropriate as the design of the study. Overall, there are three different kinds of variables in this study; one dependent (or criterion) and one independent (or predictor) variable and a moderator one. The dependent variable of the present study is EFL spelling; the independent variable is cellphone dictionary use and gender is moderator variable.

The study employed empirical type of research and it aimed at answering the following questions:

RQ1. Do using cell phone dictionaries have any effect on improving male and female Iranian high school EFL learners' spelling?

RQ2. Does interaction between gender and cellphone instruction have any effect on students' spelling?

The following research hypotheses were formed based on the research questions propose before.

H1. Using cell phone dictionaries do not have any effect on improving male and female Iranian high school EFL learners' spelling.

H2. Interaction between gender and cell phone instruction does not have any effect on students' spelling.

\section{Method}

\subsection{Subsections of Method}

Through this section it has been tried to describe the steps taken for carrying out the current study. More specifically, the chapter will provide information about the participants, materials, instruments and procedures that were employed in this study.

\subsection{Participants}

This study was conducted with 60 male and female learners, at Dinodanesh and Etrat high schools of Lordegan city in Iran.

\subsection{Sampling Procedure}

The participants were randomly selected. The spelling pretest was used to identify level of the learners and learners ' homogeneity. Among ninety learners, sixty of them were chosen based on proficiency test. The learners were divided into experimental group and control group, which each group consists of twenty learners.

\subsubsection{Sample Size}

The sample of the study were 90 intermediate Iranian EFL learners which 60 of them were selected based on 
proficiency test as main participants of the study.

\subsubsection{Measures and Covariates}

As the researcher investigated the effect of using cell phone dictionaries on improving male and female Iranian high school EFL learners' spelling, to achieve this goal the researcher performed these stages in this study, and the research was done according to these stages:

1). Ninety male and female EFL learners were chosen at high schools in Lordegan city.

2). The spelling pre-test was given to the learners and the results were analyzed in order to choose about sixty homogeneous learners.

3). The learners were divided into three groups, the first group was control group covering twenty male and female learners and the second group was the experimental group including twenty male learners, and the third one were twenty female learners. All learners groups were homogeneous and in same level.

4). The control group was received teacher instructions and some simple texts designed according to the book with scrambled words and the students had to unscramble and inserted the correct letters based on the book and teacher instruction and practiced the spelling in their note books. At the same time the experimental groups received the cell phone dictionary and the simple text the same as control group and practiced the spelling of the word into the PMD dictionary in their cell phones and completed the texts in the sheet, they practiced the spelling in the cell phone dictionary and sometimes received teacher instructions on the white board and practiced the instructions in the cell phone dictionary. The teaching lasted a month and about four weeks and two sessions at a week, each session lasted two hours.

5). At the end of the course, the spelling post-test was given to all groups of learners and learners performed that.

6). At the end, the data were collected based on the post tests and analyzed the information of groups in spelling post-test.

In this study, there was one spelling pre-test, some simple texts in a sheet, and one spelling post-test. The students used course book and cell phone dictionary and teacher guide. The teacher taught the course book through white board, book, cell phone dictionary and printed simple texts on sheet. The pre-test was comprised thirty spelling items according to course book and will give the students to identify the level and homogeneity. The sheet was comprised three simple texts and some important words in the texts were scrambled, the students completed the words and texts, by correct spelling. The printed texts were adapted for this study should be short, uncomplicated sentences throughout the text, according to the course book. The selected sentences were comprised the nouns, adjectives, verbs, adverbs by scrambling the letters, the instruction wants students to guess the correct letters and complete the words and sentences. In this study the book and teacher guide helped the students, when they could not guess the correct words, and the control group practiced the word spelling in their note books and the experimental group practiced the words in cell phone dictionary. The cell phone dictionary was PMD dictionary that installed in on cell phone and the researcher prepared the cell phone dictionary and installed it on students' cell phones in experimental group. The post-test contained thirty items according to the course that students were involved and the questions or items had different instructions. The time for teaching the students was two hours in a session.

\section{Data Analyses}

\subsection{Recruitment}

A group of 60 students took a proficiency test. The normality of this test calculated by Kolomogorov-Smirnov test and as Table 1 indicates this test was normal (Sig. 0.13>0.05).

As mentioned earlier, a group of 90 students took a proficiency test (PET-test) and 60 of them, who scored between 7 and 17 were selected to participate in this study. Table 1 shows the descriptive statistics for the scores of the learners on this test.

Table 1. Descriptive statistics for scores on proficiency test

\begin{tabular}{llll}
\hline Source & $\mathrm{N}$ & $\mathrm{M}$ & $\mathrm{SD}$ \\
\hline proficiency-test & 90 & 11.68 & 2.17 \\
\hline
\end{tabular}

The normality of scores on this test was calculated by Kolomogorov-Smirnov test to select the proper statistical tool to compare the scores on proficiency test; Table 2 clearly indicates that the scores were normally distributed 
$(\operatorname{Sig}=0.09>0.05)$.

Table 2. One-sample Kolmogorov-Smirnov test for scores on proficiency test

\begin{tabular}{lllll}
\hline $\mathrm{N}$ & $\mathrm{M}$ & $\mathrm{SD}$ & Kolmogorov-Smirnov Z & Asymp.Sig. (2-tailed) \\
\hline 90 & 11.68 & 2.17 & 1.231 & 0.096 \\
\hline
\end{tabular}

In order to ensure that the learners in three groups (MG, FG, CG) enjoyed the same level of language proficiency prior to the main study, their scores on the proficiency test were put into a One-way ANOVA (Table 3) and the results revealed that there were no significant differences across the participants on their level of proficiency $(\mathrm{p}=$ $0.80>0.05)$.

Table 3. One-way ANOVA for scores on proficiency test

\begin{tabular}{llllll}
\hline Source & Sum of Squares & df & Mean Square & F & Sig. \\
\hline Between Groups & 0.358 & 2 & 0.179 & 0.212 & 0.809 \\
Within Groups & 48.075 & 57 & 0.843 & & \\
Total & 48.433 & 59 & & & \\
\hline
\end{tabular}

Descriptive statistics for the scores of the learners on pre-test was conducted after the pre-test administration. Table 4 shows the results.

Table 4. Descriptive statistics for scores on pre-test by gender

\begin{tabular}{lllll}
\hline Source & Gender & N & M & SD \\
\hline Experimental group 1 & Female & 20 & 12.95 & 0.368 \\
Experimental group2 & Male & 20 & 13.42 & 1.253 \\
Control group & Male \& Female & 20 & 12.72 & 0.463 \\
\hline
\end{tabular}

As mentioned earlier, this test was administered to make sure if they were homogeneous in terms of their reading ability. The normality of this test was calculated by Kolomogorov-Smirnov test and Table 5 indicates the results $(\mathrm{Sig}=0.28>0.05)$.

Table 5. One-sample Kolmogorov-Smirnov test for scores on pretest

\begin{tabular}{lllll}
\hline $\mathrm{N}$ & $\mathrm{M}$ & $\mathrm{SD}$ & Kolmogorov-Smirnov Z & Asymp.Sig. (2-tailed) \\
\hline 60 & 13.03 & 0.728 & .983 & 0.289 \\
\hline
\end{tabular}

Since the distribution of the scores on pre-test was normal, a One-way ANOVA was run to see if any differences existed among the three groups in terms of their spelling ability. As Table 6 indicates there was not any significant difference on the pretest scores across the groups $(\mathrm{F}=2.90$, $\mathrm{Sig}=.063)$. Thus, it can be concluded that the three groups enjoyed the same level of spelling ability.

\subsection{Statistics and Data Analysis}

Table 6. One-way ANOVA for scores on pretest

\begin{tabular}{llllll}
\hline Source & Sum of Squares & df & Mean Square & F & Sig. \\
\hline Between Groups & 2.894 & 2 & 1.447 & 2.902 & 0.063 \\
Within Groups & 28.426 & 57 & 0.499 & & \\
Total & 31.320 & 59 & & & \\
\hline
\end{tabular}

The post-test of this study was the same test as pre-test. Descriptive statistics was computed after the post-test administration. Table 7 shows the results. The three groups performed differently and showed a gain but the two treatment groups' gains were substantial. MG showed higher mean so, it can be concluded that MG performed 
better than both FG and CG. Figure 1 shows a comparison between the groups' mean scores on the posttest and regarding gender, there was no significant difference between males and females.

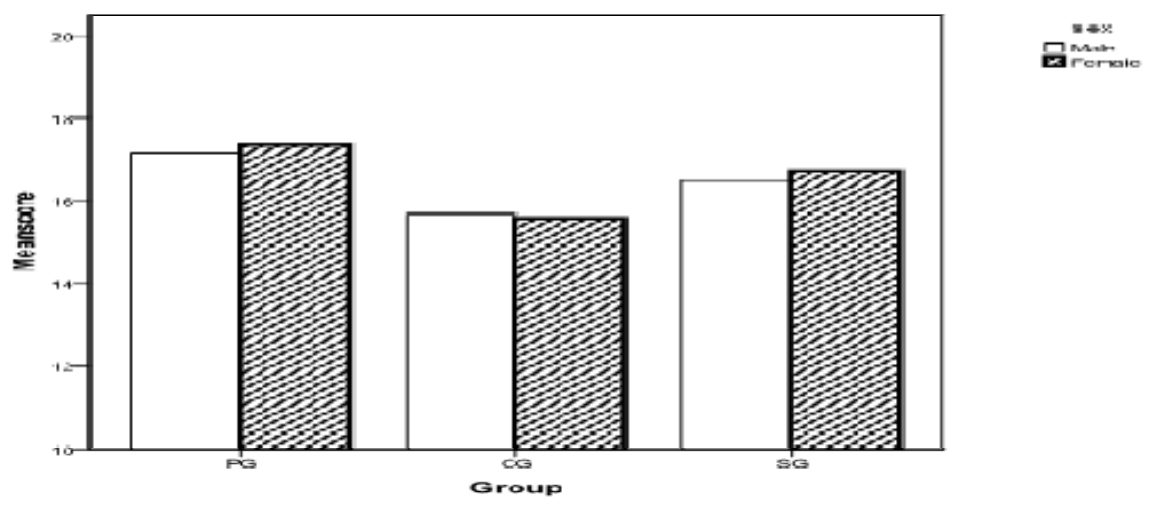

Figure 1. Descriptive statistics for scores on post-test by gender

Table 7. Descriptive statistics for scores on post-test by gender

\begin{tabular}{lllll}
\hline & Gender & N & M & SD \\
\hline Experimental group 1 & Female & 20 & 16.48 & 0.423 \\
Experimental group2 & Male & 20 & 17.16 & 0.429 \\
Control group & Male \& Female & 20 & 15.63 & 0.423 \\
\hline
\end{tabular}

Before discussing the main results of two-way ANOVA, it should be mentioned that the groups enjoyed homogeneous variances (Levene's F=1.46, Sig $>0.05$ ). Table 8 shows the result.

Table 8 . Test of homogeneity of variances for scores on post-test

\begin{tabular}{llll}
\hline $\mathrm{F}$ & $\mathrm{df1}$ & $\mathrm{df2}$ & Sig. \\
\hline 1.463 & 5 & 54 & .217 \\
\hline
\end{tabular}

As there are two independent variables, namely cell phone dictionary instruction and gender, the present data analysis utilized a two-way ANOVA to explore the impact of sex and using cell phon dictionary on spelling ability. As can be seen in Table 9 there was a statistically significant main effect for group $(\mathrm{p}=0.000<0.05)$. Using Cohen's (1988) criterion, the effect size for this difference (partial eta squared $=.562$ ) can be considered as large. These results suggest that using cellphone had a significant effect on students' spelling. Thus, the first null-hypothesis predicting that using cell phone dictionaries do not have any effect on improving male and female Iranian high school EFL learners' spelling" was rejected. As shown in Table 9 the p-value of gender was higher than $0.05(.50>.05)$. It indicates the fact that there was no significant main effect for gender and gender had not a significant effect on students' spelling.

The interaction effect between gender and cell phon instruction was not statistically significant either $(.65>.05)$. This indicates that there was no significant difference in the effect of strategy type spelling for males and females. Thus, the second hypothesis claiming that "interaction between gender and type of strategy does not have any effect on students' spelling" has also been confirmed. Figure 2 indicates a plot of the listening scores for males and females, across the three groups. 
Table 9. Two-way ANOVA for scores on post-test

\begin{tabular}{lllllll}
\hline Source & SS & Df & Mean Square & F & Sig. & Partial Eta Squared \\
\hline Group & 26.585 & 2 & 13.293 & 34.656 & $.000^{* * *}$ & .562 \\
Gender & .171 & 1 & .171 & .445 & .508 & .008 \\
Group*Gender & .329 & 2 & .165 & .429 & .653 & .016 \\
Error & 20.712 & 54 & .384 & & & \\
Total & 16369.600 & 60 & & & & \\
\hline
\end{tabular}

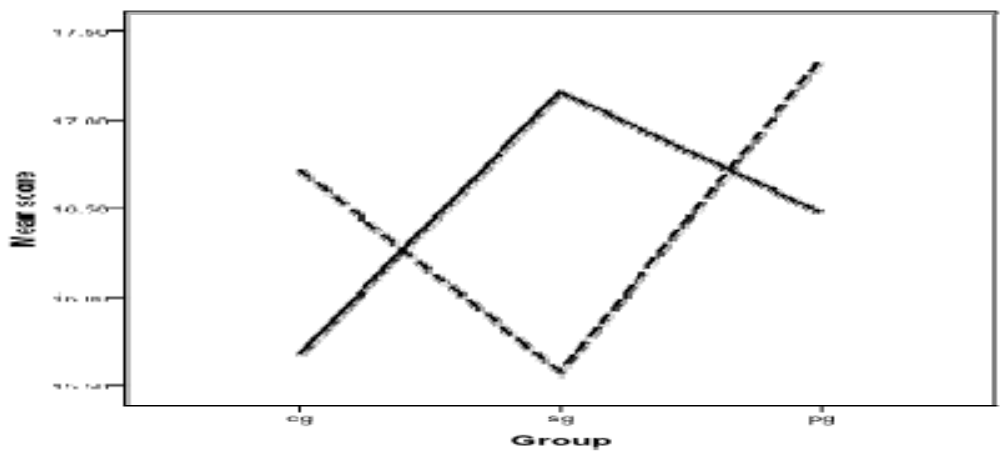

Figure 2. Mean performance on posttest across the groups

A Post-hoc multiple comparisons was run to examine the differences between the three groups statistically and to pin down where the differences exactly lie, as shown in Table 10. The results obtained from these comparisons indicated that the mean score for FG $(\mathrm{M}=16.60)$ was significantly different from both $\mathrm{MG}(\mathrm{M}=17.25)$ and $\mathrm{CG}$ $(\mathrm{M}=15.63)$ and also the mean score for $\mathrm{MG}(\mathrm{M}=17.25)$ was significantly different from $\mathrm{CG}(\mathrm{M}=15.63)$. These comparisons coupled with the descriptive statistics presented in Table 7 revealed that experimental groups outperformed control group.

Table 10. Post-Hoc tests (multiple comparisons) of the three groups for scores on post-test

\begin{tabular}{lllllll}
\hline \multirow{2}{*}{ Group } & & \multirow{2}{*}{ Mean Difference } & \multirow{2}{*}{ Std. Error } & \multirow{2}{*}{ Sig. } & \multicolumn{2}{c}{$95 \%$ Confidence Interval } \\
\cline { 6 - 7 } FG & MG & $-.6500^{*}$ & .19585 & .005 & -1.1220 & -.1780 \\
& CG & $.9700^{*}$ & .19585 & .000 & .4980 & 1.4420 \\
& CG & $1.6200^{*}$ & .19585 & .000 & 1.1480 & 2.0920 \\
\multirow{2}{*}{ MG } & FG & $.6500^{*}$ & .19585 & .005 & .1780 & 1.1220 \\
\multirow{2}{*}{ CG } & M G & $-1.6200^{*}$ & .19585 & .000 & -2.0920 & -1.1480 \\
& F G & $-.9700^{*}$ & .19585 & .000 & -1.4420 & -.4980 \\
\hline
\end{tabular}

\section{Discussion}

The present study aimed at investigating the effect of using cell phone dictionaries on improving Iranian high school mail and female EFL learners' spelling. The findings of the study revealed that using cell phone dictionaries could improve the spelling of Iranian high school EFL learners. To summarize the major findings of this study in terms of research hypotheses set at the outset, the null hypothesis predicting using cell phone dictionaries does not have any effect on improving Iranian high school EFL learners' spelling was rejected in this study. This can be due to the using cell phone dictionaries activities that were used during the treatment period. Therefore, the effects of using cell phone dictionaries on improving learners' spelling were confirmed in this study. Additionally, the experimental group indicated more ability in spelling. In fact, the results revealed that the systematic variation between group's performances on post-test was due to the manipulation of experimental treatment. Accordingly, it can be speculated that using cell phone dictionaries affected the spelling ability of the experimental group. The findings of the present study were in line with the findings of (Tick, 2009), who have posited mobile phone technology may lead to positive effects in learning environments because of its widespread use and functions such as mobility, reach ability, localization and personalization. The findings also echo those of the study conducted by (Davies, 2002), showing that vocabulary learning via mobile phones can be more effective than massed 
vocabulary learning through the paper medium. The results of the present study are in congruence with previous studies (Thornton \& Houser, 2005; Clark et al., 2008; Fotouhi-Ghazvinchi et al., 2009; Motallebzadeh et al., 2011; Khazaei \& Vahid Dastjerdi, 2011) reporting that the use of mobile phone ś features has had positive effects on student's language learning. The findings of this study are also at odds with those of Salaberry (2001) who claims that mobile phones are not effective tools for learning. Finally, the findings demonstrated that the subjects took advantage of using cell phone dictionaries and showed a meaningful difference due to the treatment effect. In other words, it posited that the more opportunities for using cell phone dictionaries there are, the more likely acquisition is to happen.

It also should be mentioned that, the interaction effect between gender and cell phone instruction was not statistically significant. This indicates that there was no significant difference in the effect of strategy type for males and females.

Better performance of the students of the experimental group which was determined by the mean-comparison with those of the control group, was somehow anticipated by the researcher observing the strongly motivated learners of the experimental group who also showed a higher degree of openness to experience during the course of the study than the students of the control group. Experimental students showed a higher inclination to using cell phone dictionaries with the aim of learning spelling of English words compared to students of the control group who preferred to use book and practice words in note book. One of the most salient privileges of using cell phone dictionaries seems to be that language development of students of the experimental group is technology based. It can be concluded that the use of cell phone dictionaries has significantly affected the students' performance in experimental group. As the findings of this study demonstrate cell phones could be widely used as a pedagogical tool for facilitating the foreign language spelling learning. Thus, these findings highlight the importance of using cell phone dictionary and its potentials as an attractive path through which success of teaching and learning process can be enhanced. In summary this paper was generally an attempt to assess the effectiveness of using cell phone dictionaries for promoting male and female Iranian high school EFL learners' spelling, and showed that using cell phone dictionaries has positive effect on spelling.

The study has some limitations concerning its design. One strong limitation was the small number of participants in the experiment. It is normally very difficult to gather participants for experiments, especially if it involves specific skills and demands that participants return for several sessions on different days. The age range of the learners was different in groups.

\section{References}

Beatty, K. (2003). Teaching and researching computer assisted language learning. Essex: Pearson Education.

Canny, J. (2010). Microsoft research program. Retrieved from http://research-microsoft.com/enus/collaboration/papers/berkely.pdf

Clark, P., Keing, C., Lam, P., \& Mc Naught, C. (2008). Using SMSs to engage students in language learning. In E. R. Weipp \& J. Luca (Eds.), ED-MEDIA 2008 (pp. 6132-6141). Paper presented at the 20th annual World Conference on Education a Multimedia, Hypermedia \& Telecommunications, Vienna and Austria.

Colpaert, J. (2004). From courseware to course wear? Computer Assisted Language Learning, 17, 261-266. http://dx.doi.org/10.1080/0958822042000319575

Fotouhi-Ghazvinchi, F., Earnshaw, R., Robinson, D., \& Excell, P. (2009). The MOBO City: A mobile game package for technical language learning. IJIM, 3(2), 19-24.

Khazaei, S., \& Vahid Dastjerdi, H. (2011). An investigation into the impact of traditional vs. blended teaching of EFL learners' vocabulary acquisition: M-Learning in focus. International Journal Humanities and Social Science, 1(15), 202-207.

Motallebzadeh, K., \& Ganjali, R. (2011). SMS: Tool for L2 vocabulary retention and reading comprehension ability. Journal of Language Teaching and Research, 2(5), 1111-1115. http://dx.doi.org/10.4304/jltr.2.5.1111-1115

Prensky, M. (2005). What can you learn from a cell phone? Almost anything! The innovate gateway 1 (June/July). Retrieved from http://www.innovateonline.Info/index.php?view=article\&id=83

Salaberry, M. R. (2001). The use of technology for second language learning and teaching: A retrospective. Modern Language Journal, 85, 39-56. http://dx.doi.org/10.1111/0026-7902.00096

Thornton, P., \& Houser, C. (2005). Using mobile phones in English education in Japan. Journal of Computer Assisted Learning, 21(3), 217-228. http://dx.doi.org/10.1111/j.1365-2729.2005.00129.x 
Tick, A. (2009). From Computer Assisted Language Learning to Computer Mediated Language Learning. Retrieved from https://www.researchgate.net/publication/228834158_From_Computer_Assisted_Language_Learning_to_C omputer_Mediated_Language_Learning

\section{Copyrights}

Copyright for this article is retained by the author(s), with first publication rights granted to the journal.

This is an open-access article distributed under the terms and conditions of the Creative Commons Attribution license (http://creativecommons.org/licenses/by/4.0/). 